\title{
Blogging about climate change in Russia: activism, scepticism and conspiracies
}

\section{Introduction}

The internet can be seen as a useful tool in fighting elite-imposed traditional media discourse. Thus in the case of climate change communication in Russia, new media can be a platform for an alternative discussion by challenging state climate policy. Russia is one of the key players in international climate change policy as it is among the world's largest GHG emitters and often presents obstacles during key moments of the climate change negotiation process (Andonova 2008). It is, therefore, very important to understand how climate change risks are presented and communicated in Russia. However, as the latest analysis of the literature on climate change communication (Schafer and Schlichting 2014) has demonstrated, Russia remains significantly understudied. Despite the development of climate change communication studies, the new media sector is still underrepresented within the body of academic enquiries (Schafer 2012). This article contributes to the literature gap in both areas by concentrating on climate change communication in Russian new media, and in particular, in one of Russia's most popular blogging platforms LiveJournal (Zhivoi Zhurnal) (Koltsova et al. 2016, Koltsova and Scherbak 2014).

Here, new media is understood as 'the combination of material artefacts, people's practices, and the social and organisational arrangements involved in the process of human communication' (Lievrouw 2011: 15), whilst blogging is not seen as a proxy for all new media, but as one of its variations. Flew (2011: 96) defines blogs as 'user-generated websites where entries are made either by individuals or by groups, in an informal journal style [...] they are typically interactive in their nature, and networked in their form'., To distinguish blogs from other forms of social media, it is important to consider that in this case 'the maintenance of a diary prevails over the establishment of social contacts' (Koltsova and Scherbak 2014: 2). Arguably, new media allow us to bring the climate change discussion to the next level by openly debating the problem (Freelon 2013) and breaking the traditional one-way communication process. By studying how climate change is covered online we can explore how climate change discourse is formed, how the public perceives and reacts to it, the links people create and what kind of responses they make (Chay and Sasaki 2011).

This research article aims 1) to define the dominant themes ('discursive categories') within the studied body of data; 2) to analyse how these themes contribute to the construction of climate change discourse in Russia; and 3) to investigate whether Russian blogs act as an alternative channel to the elite-dominated climate change discourse created in the traditional media. This is achieved through the discourse analysis of 374 blog entries published on LiveJournal in 2014 around three climate change-related events: summer flooding in Siberia, the People's Climate March, and the UN Climate Change Conference in Lima. The article argues that whilst the studied blog entries present an array of topics which certainly contribute to and diversify the public discourse, they fail to challenge the existing official position on the state's climate policy.

The article, firstly, looks at the existing academic debates on the role of new media in communicating climate change, and examines the internet's place in Russia. After providing context on Russia's climate policy and outlining methodological considerations, the findings are presented and discussed. 


\section{Climate change and new media}

It is argued that that new media are able to challenge the scientific monopoly on climate change knowledge through the unrestricted flow of information (O'Neill and Boykoff 2011), intensify the process of global integration (Rantanen 2001) and contribute to the application of new research ideas in climate change science (Newell and Dale 2015). Looking specifically at the role of blogs in climate change communication in Norway, Ytterstad (2008: 78) notes that 'through blogs we can nevertheless observe how meaning and perspectives are given to the public without journalistic intermediaries', therefore, making the whole process more democratic and accessible. Katz-Kimchi and Manosevitch (2015) in their analysis of environmental NGOs observe that social media (as a variation of new media) contribute to online mobilisation and the overall success of climate change related campaigns. Similarly, Takahashi et al. (2015) state that 'the internet presents a paradox since it does not allow physical social interactions, but at the same time can create and reinforce social unity'. Furthermore, due to 'the social and participatory aspects of social media 'and fast growing popularity, their importance will continue to rise and in this regard social media can surpass traditional media in their role 'in shaping public engagement with this important global challenge [climate change]' (Williams et al. 2015: 137).

Despite the outlined positive tendencies, some scholars are cautious in evaluating new media's contribution. For example, O'Neill and Boykoff (2011: 248) warn their readers that all of the attributed positive effects of new media have a flip side: the spread of 'disinformation' (along with information), instead of unifying various social groups, new media can 'increase fragmentation' or only reach people who are already committed. In some cases, new media fail to act as an alternative platform for climate change discussions, and instead reproduce the discourse of traditional media (Bosch 2012). Lockwood (2008: 2) brings our attention to 'the force of new media in promulgating sceptical positions' where they make it even easier to question climate change science. Martin and Rice (2014: 347) echo these concerns by stating that a large proportion of comments overly concentrate on questioning the 'climate science consensus, dissent and uncertainty' by making climate science even more vulnerable (see also Ladle et al. 2005). Furthermore, Newell and Dale (2015: 225) state that due to the abundance of information shared online, climate change knowledge can become invisible or overshadowed by unrelated "noise"'. In addition, new media, praised for their communication freedom, are not completely free of censorship, as Uldam and Askanius (2013) suggest: climate change activists do feel certain restrictions imposed onto them by the new media structure, which in some instances exposes them to insecurity from the users' hostility.

Elgesem et al. (2015) proclaim blogging platforms to be a great source of data for the study of public perception and relations between different groups of climate change sceptics and accepters. However, such study has to be approached with caution as the same blog entry can have very different effects on various groups of people (Matthews 2015: 165). The new media role in climate change communication in general, and the role of blogging in particular, can also vary depending on the specific social, economic, political or cultural context, which is why it is important to look specifically at its development and specification in Russia - the case study of this research inquiry. 


\section{New media in Russia}

Since 2000 we have observed a rapid increase in internet penetration and usage in Russia. At the time of data collection for this study, 62 percent of Russians were accessing the internet monthly and 51 percent were going online on a daily basis (FOM 2014). In 2016 these figures increased respectively to 70 percent and 57 percent (FOM 2016a). These data should be treated with some caution, in order not to make unjustifiable extrapolations (Alexanyan 2009). Russia follows the world's trends with its internet users having better education, income or being younger than people who are still left on the other side of the digital divide (FOM 2014).

When the internet was introduced to the wider public in Russia, some saw it as a future cornerstone for the national development of freedom of speech (Vinogradov 2006). This 'cyber-optimism' (Oates 2013) reflected on people's belief in the internet's intrinsic capacities to allow for a wide range of ideas whilst avoiding the state's (or anyone else's) control. Arguably, new media are more important in authoritarian regimes than democratic ones. Since the traditional media are highly centralised, the internet assists 'collective mobilisation' (Koltsova and Scherbak 2014: 2). Over time, 'cyber-optimism' in Russia has been confronted by 'cyber-scepticism', which underlines the internet's failure to challenge the 'well-established patterns of power' (Fossato et al 2008: 53). Since the early 2010s Russian officials have paid greater attention to the internet. They started to use it in their work (similarly to their Western colleagues) (Renz and Sullivan 2013) and became more proactive in controlling online activities that undermine the regime's establishments. For instance, in summer 2016 the lower house of Russia's parliament adopted an anti-terrorism 'Yarovaya bill' which is feared to be another tool to censor internet activity. The damaging repercussions of this piece of legislature have been highlighted by Reporters Without Borders (2016), 'as the security services interpret the charges of "terrorism" and "extremism" very broadly, an enhanced crackdown on social network users can be expected'. Schmidt and Teubener (2009 cited in Panchenko 2011: 113) argue that RuNet $^{1}$ has acquired the status of a successful tool of political manipulation, and, as a result, it has lost public trust in new media as a potential platform for democratic discussion.

As the section below demonstrates, the strong presence of the Russian state also defines the country's climate affairs.

\section{Russia and climate change: media and state policy}

Russia's carbon intensive economy (due to its northern location and excessive reliance on fossil fuel exports) makes it the fifth largest GHG emitter in the world (World Bank 2012). This also makes Russia a significant player in global climate change politics (Buchner and Dall'Olio 2005). Following the economic collapse that proceeded the Soviet Union's disintegration, Russia's GHG emissions fell well below the permitted levels as stipulated in the Kyoto Protocol ${ }^{2}$. Yet Russia took its time (over six years) to agree to sign and ratify the

\footnotetext{
${ }^{1}$ Russian language internet.

${ }^{2}$ In 1990 (the base year) Russia's total GHG emissions without LULUCF constituted 3941300 (kt CO2 equivalent), by 2000 it fell to 2430552 and in 2013 increased to 2799434 (UNFCCC 2015).
} 
Protocol $^{3}$. Whilst this contribution to the global climate change regime has been praised by the Russian authorities and national media, as it finally brought the Protocol in force (e.g. Izvestiya 1997; see also Andonova 2008), Russia was also widely criticised for this extensively prolonged negotiation process (Korppoo 2008; Poberezhskaya 2016). Traditionally, Russia's climate change policy has been influenced by the prioritisation of economic development (Henry 2010), the close connection between the state and the energy sector (Buchner and Dall'Olio 2005), the downgrading of the environmental ministry (Oldfield 2001), and the low level of awareness and concern among the public (World Bank 2010).

In 2009, Russian climate change policy started to become more proactive and coherent (beginning with the acceptance of the Climate Doctrine and culminating with the signing of the Presidential Decree (N 752, 2013) 'On the Reduction of GHG Emissions'). It actively takes part in the negotiation process and insists on the 'common but differentiated responsibilities' approach to the new climate agreement (Bedritsky 2014). The positive tendencies in Russia's climate policy can be explained, through the realisation of its growing climate vulnerability (Roshydromet 2014) and understanding of the potential economic benefits due to energy efficiency policies (Poberezhskaya 2016).

Studies of the role of traditional media in climate change communication in Russia have demonstrated a correlation between the media's coverage and the state's move towards better climate change policies: where media attention grew substantially after the political changes outlined above (Poberezhskaya 2016; Tynkkynen 2010; Wilson Rowe 2009). The influence of the political discourse on media representations of climate change has also been demonstrated by the media's tolerant coverage of national political agendas and the prioritisation of state sources of information as key journalistic sources. Therefore, it is important to explore whether the Russian online discourse on climate change issues exhibits the same characteristics as the traditional media: a tendency to be prompted by state activity and to be dependent on official state sources.

\section{Methodology and data}

Critical Discourse Analysis (CDA) is widely used in studies of climate change media coverage (e.g. Carvalho 2008; Olausson 2009) which helps scholars to determine power relations surrounding the topic (van Dijk 2001). The framework for the media analysis has been borrowed and adapted from Carvalho (2008: 167) who suggests that these analytical steps can be applied to any types of news texts (including online news). The textual analysis includes:

- Layout (headlines, lead paragraph, conclusion, any visual elements);

- Actors (Who are the sources of information? How do they construct the problem?);

- Language (the choice of emotive words, verbs, syntaxes, metaphors);

- Objects (similar to the frames, shows how the main topic is presented in the article).

\footnotetext{
${ }^{3}$ Whilst the Kyoto Protocol was adopted on 11 December 1997 and Russia signed it on 11 March 1999, it was not approved at the national level until 18 November 2004 and was then enforced on 16 February 2005 (UNFCCC n.d.).
} 
A single blog entry is seen as a representation of a certain 'episode' within the overall 'narrative structure' of the blog created by its author (Rettberg 2008: 111) which intends to correspond with certain goals or ideas the blogger wants to communicate to his/her audience. This approach allows us to explore a range of the existing frames within the analysed data which is then compared to the official discourse on climate change in Russia which will assist in testing the hypothesis on blogs serving as a tool in creating an alternative climate change discussion.

Compared to other social media platforms (e.g. to the microblogging platform Twitter), the types of blogs studied here are allegedly less dependent on reproducing traditional media content (Koltsova and Shcherbak 2014), therefore, they allow us to look beyond the mainstream climate change discourse and get a sense of personal understanding of the problem (Koteyko et al. 2013). In Russia, blogging platforms such as LiveJournal also have features of social media combining 'personal diary entries, blog posts, comments, communities, and friendship networks' (Alexanyan 2009: 4) and represent a very useful research object full of rich qualitative data.

CDA suggests looking at the text within a 'wider social context' (Carvalho 2008: 171) for the 'comparative-synchronic' and 'historical-diachronic' analysis. Whilst the former proposes looking at how the same event/topic has been addressed by various authors or media outlets, the latter looks at the evolution of the discourse over certain periods (ibid). However, in the case of blogging, the pure numbers have to be considered with caution, since they can be affected by the bloggers' desire to remove their posts or hide them from a public search. As more time passes after the event it becomes more likely that some of the entries will disappear. Therefore, the suggested discourse analysis will not concentrate on the 'historicaldiachronic' aspect of the research study, but on the range of existing frames and themes.

In order to conduct an intensive qualitative text analysis, the data collection was restricted to texts published in 2014 within a month of three major climate change related events ('critical discursive moments' Carvalho (ibid: 166)). These events are: summer flooding in Siberia (20 May - 20 June 2014), the People's Climate March (5 September - 5 October 2014) and the UN Climate Change Conference in Lima (20 November - 20 December 2014). The texts were collected through the online Russian-language search engine Yandex.ru, ${ }^{4}$ with the keywords: climate change, global warming and greenhouse effects (izmenenie klimata, global'noe poteplenie, parnikovyi effekt - with all their possible grammatical variations). The initial search resulted in 557, 525 and $502^{5}$ blog entries per event, respectively. During the preliminary reading of the data, relevance sampling was applied to eliminate duplicated texts or entries which mention climate change in an unrelated context. $^{6}$ The final body of data consisted of 374 blog entries with 77 of them published during

\footnotetext{
${ }^{4}$ The search was restricted to livejournal.com and Russia for the registered location of the bloggers.

${ }^{5}$ These results have to be taken cautiously due to the limitations of the online search engines used, which slightly vary in the number of blog entries found on different days. The search was conducted multiple times to diminish this error.

${ }^{6}$ For example, the greenhouse gas effect can be mentioned in relation to gardening.
} 
the flooding events, 142 during the People's Climate March and 155 blog entries published around the Climate Change conference in Lima.

\section{Analysis}

The diversity of the analysed blog entries constituted one of the most striking characteristics of the online discourse. Due to the lack of restrictions on the structure, grammar and composition of the entries, the texts can include combinations of text, video and photographs with each element contributing to the overall argument and 'producing meaning' (Carvalho 2007: 227). The entries can also either contain the re-posted traditional media publication, the author's personal account of the event, or a combination of both. The diversity was also manifested in the extremes present in the vocabulary and grammatical structures of the blogs: from the academic formal discussion of climate change to colloquial, highly emotive expression of bloggers' opinions on the subject matter. Interestingly, despite a preconception, that it is usually climate deniers or sceptics who are quite aggressive or emotive in expressing their views, these linguistic choices were pursued by various bloggers regardless of their views on anthropogenic climate change. For instance, the blogger dirty_as_dj (2014) shares his personal account of changes in weather patterns:

I remember, in February I was drinking with some friends, and there was one funny guy. He was telling us, that there is no global warming and that some

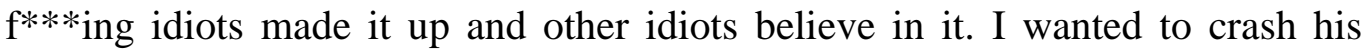

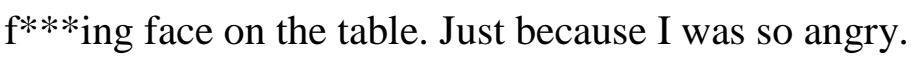

Whilst another blogger (kungurov 2014), in his blog entry 'Zombie-liberals will turn green' ('zombo-liberasty pozeleneiut'), is similarly expressive in discrediting the anthropogenic climate change theory and the environmentalists - whom he refers as 'ecofascists' that create 'eco-hysteria' in the world:

With regard to the so-called anthropogenic impact, as a main factor of global warming, this is such ridiculous $b * 11$ sh*t, I feel embarrassed even to talk seriously about it.

The imperative nature of the created discourse around climate change makes both examples quite similar, even though they represent polar opposite views of the problem.

The comprehensive application of the above mentioned methodological tools has allowed for the identification of the following discursive categories, or frames within the analysed body of text which have persistently reappeared throughout all three events: 'conspiracies of climate change'; 'climate change impact'; 'political games of climate change' and 'online (anti-)environmentalism'. Table 1 demonstrates how, based on the applied methodological steps, these categories were formed, whilst Figure 1 shows how they were distributed across the studied periods.

Table 1. Discursive categories with examples

\begin{tabular}{|l|l|l|l|l|}
\hline $\begin{array}{l}\text { Discursive } \\
\text { category }\end{array}$ & Layout & Objects & Actors & Language \\
\hline $\begin{array}{l}\text { Conspiracies of } \\
\text { climate change }\end{array}$ & $\begin{array}{l}\text { Use of 'hard } \\
\text { evidence' } \\
\text { (photographs, }\end{array}$ & $\begin{array}{l}\text { Climate change } \\
\text { is not happening; }\end{array}$ & $\begin{array}{l}\text { Politicians } \\
\text { (West vs. } \\
\text { Russia); }\end{array}$ & $\begin{array}{l}\text { 'Western plot'; } \\
\text { 'olimate; }\end{array}$ \\
\hline
\end{tabular}




\begin{tabular}{|c|c|c|c|c|}
\hline & $\begin{array}{l}\text { 'secret' } \\
\text { documents, } \\
\text { graphs) }\end{array}$ & $\begin{array}{l}\text { we are being } \\
\text { fooled }\end{array}$ & $\begin{array}{l}\text { scientists, } \\
\text { journalists, } \\
\text { bloggers }\end{array}$ & $\begin{array}{l}\text { weapon', 'myth', } \\
\text { 'lie', 'deception' }\end{array}$ \\
\hline $\begin{array}{l}\text { Political games } \\
\text { of climate } \\
\text { change }\end{array}$ & $\begin{array}{l}\text { An explanatory } \\
\text { description of } \\
\text { political } \\
\text { negotiations }\end{array}$ & $\begin{array}{l}\text { Climate change } \\
\text { problem requires } \\
\text { the attention of } \\
\text { the world. } \\
\text { Climate change } \\
\text { is a political } \\
\text { game }\end{array}$ & $\begin{array}{l}\text { Politicians, } \\
\text { journalists, } \\
\text { NGOs }\end{array}$ & $\begin{array}{l}\text { 'Capitalism as a } \\
\text { main problem'; } \\
\text { 'Russia has been } \\
\text { presented with } \\
\text { dignity'; 'global } \\
\text { warming will } \\
\text { give a great } \\
\text { advantage' }\end{array}$ \\
\hline $\begin{array}{l}\text { Climate change } \\
\text { impact }\end{array}$ & $\begin{array}{l}\text { The screenshots } \\
\text { from the } \\
\text { disaster movies; } \\
\text { photographs of } \\
\text { climate change } \\
\text { consequences }\end{array}$ & $\begin{array}{l}\text { Climate change } \\
\text { is a real threat; } \\
\text { apocalypse is } \\
\text { unavoidable }\end{array}$ & $\begin{array}{l}\text { Scientists; } \\
\text { Hollywood } \\
\text {; bloggers; } \\
\text { journalists }\end{array}$ & $\begin{array}{l}\text { 'destruction'; } \\
\text { 'unavoidable } \\
\text { end'; } \\
\text { 'catastrophic', } \\
\text { 'danger', } \\
\text { extremes' }\end{array}$ \\
\hline $\begin{array}{l}\text { Online (anti-) } \\
\text { environmentalis } \\
\mathrm{m}\end{array}$ & $\begin{array}{l}\text { Environmental } \\
\text { appeal to } \\
\text { join/not to join } \\
\text { the campaign; }\end{array}$ & $\begin{array}{l}\text { Environmentalist } \\
\text { s cannot be } \\
\text { trusted; } \\
\text { Environmentalist } \\
\text { s should unite in } \\
\text { a climate change } \\
\text { fight }\end{array}$ & $\begin{array}{l}\text { Activists; } \\
\text { bloggers, } \\
\text { politicians, } \\
\text { journalists }\end{array}$ & $\begin{array}{l}\text { 'Save the ocean', } \\
\text { 'join the action', } \\
\text { 'the only } \\
\text { chance'; } \\
\text { 'eco-fascist', } \\
\text { 'environmental } \\
\text { Taliban'. }\end{array}$ \\
\hline
\end{tabular}

Figure 1. Number of the discursive categories over the selected events.

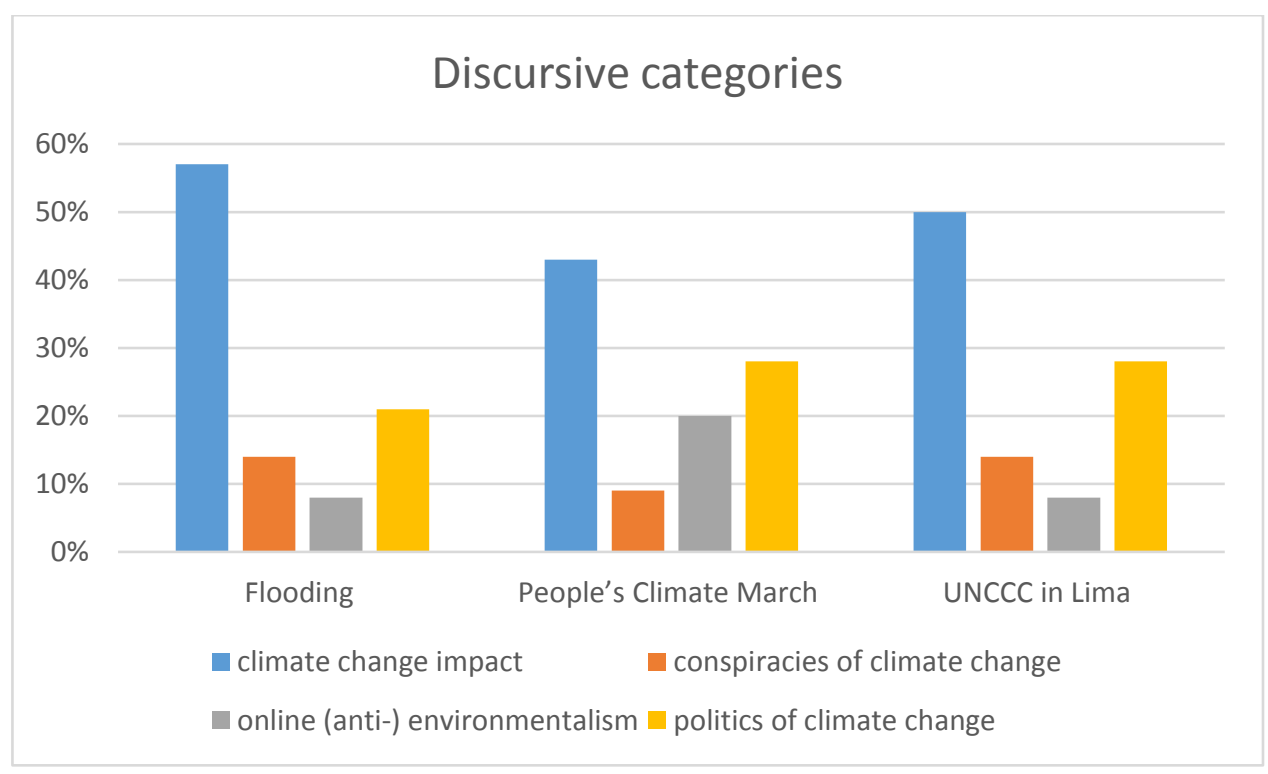

Conspiracies of climate change: 'they all lie to us'

The category 'conspiracies of climate change', whilst seemingly the most colourful and argumentative, was also the least popular $(\mathrm{n}=45,12 \%)$ (see Figure 1). In the blog entries 
aiming to unravel various conspiracy theories in some ways concerning climate change, the authors act as the discoverers of the 'truth' who aim to warn people, making themselves the main 'actors' and 'sources of information' on the subject matter. The objects of these conspiracy theories vary from climate change being a complete myth (a Western plot created to undermine the economies of developing states, $n=9,20 \%$ ) to theories which deny its anthropogenic character $(n=28,62 \%)$. The latter category varied with bloggers insisting that the 'real reasons' behind the climate apocalypse are the changes in the Earth's axis, modifications in the planet's natural movements, a swapping of the magnetic poles, or a climate weapon.

Regardless of the articles' explanation of why anthropogenic climate change should be regarded as a hoax, most followed a very similar style and structure - with the arguments presented in the form of an investigation and pseudo-scientific language used to add authority. Whilst the environmentalists' scientific authority is disregarded and activists are seen as part of the 'elite groups' who fool people. An example of this type of storyline could be seen in the blog entry titled 'Summer snow - oscillations of the Earth become more obvious' (Eroshin 2014). The list of the diary-like entries of abnormal weather events that took place throughout the world in the preceding year is aimed at convincing the reader of an extra-terrestrial cause of climate change. The author offers a discussion on the evidence of Planet X's impact on Earth's axis shift (all supported by graphs, photos and maps). The blogger also invites his readers to conduct their own experiment in observing changes in the positions of the Sun and Moon towards Earth. This direct engagement with his audience continues in the comments section where readers and the blogger supply further evidence and exchange observations re-enforcing their already existing beliefs. In terms of the lexical and syntaxes choices, the text is full of very strong vocabulary and grammatical structures: 'it is obvious', 'the best evidence', 'this is your evidence!', 'the change is so clear!' In conclusion the author identifies who is to blame for deceiving us ('NASA and other elites').

The conspiratorial blog entries' categorical nature refutes any possibilities of engaging with other arguments in support of anthropogenic climate change. As Lewandowsky (2014) argues, 'one known element of conspiratorial thinking is its "self-sealing" quality, whereby evidence against a conspiratorial belief is re-interpreted as evidence for that belief'. This notion of the impossibility to engage in any contrastive discussion makes this discursive category very powerful despite its small numbers. Interestingly, the conspiracies of climate change are not only promoted by climate deniers or sceptics but also by people on the other side of the debate (e.g. environmental activists suggesting that industries heavily invest in changing public opinion). Arguably, both sides of the argument are damaging to the scientific discourse of climate change as they 'create a climate of uncertainty and mutual distrust' (Douglas \& Sutton 2015: 102). It was also shown that compared to the discourse in traditional media and general public interest, the blogosphere tends to linger on the sceptical arguments, conspiratorial explanations and any negativity associated with climate change's scientific discussion (Lewandowsky 2014), therefore, making a false impression of the problem and its public perception. As demonstrated below, conspiratorial 'seeds' could be seen in all other groups of texts, making this category even more prominent.

\section{Climate change impact: 'doomsday is approaching'}


Discussions of climate change consequences constituted the most popular category $(n=182$, $48 \%$ ). As research studies conducted in other geographical areas claim, people who experience extreme weather events (including flooding) are more likely to see climate change as a real threat to them and their surroundings (e.g. Spence et al. 2011), therefore, it has been suggested that the discussion of climate change's impact should have prevailed during the flooding in Russia. Interestingly, despite the obvious demonstration of the abnormal weather, only six entries were identified which connected the floods with global warming. This finding requires further investigation on whether flooding, indeed, does not imply a strong connection with climate change for the Russian public.

Overall, the category of 'climate change impact' provided the most information on causes and consequences of climate change with a wide range of specific examples of how it affects us, appealing to scientists or environmentalists as the main sources of information. At the same time, the substantial number $(n=36,20 \%)$ of entries within this category has taken the discussion to the extremes with the re-telling of alarmist and even 'apocalyptic' messages. In some instances, bloggers referred to climate change as a main reason for the disappearance of ancient civilisations. Even though these specific entries do not talk about anthropogenic climate change, they do contribute to the construction of climate change as a major threat to human existence. Whilst the impact of modern climate change is presented within two categories: as a threat to eco-systems (for instance, penguins that 'need our help' or 'extinct' polar bears (e.g. Drobyshev 2014) are popular examples of charismatic megafauna, $n=45$, $25 \%)$ or as a threat to the state $(n=33,18 \%)$. In these examples, highly emotive vocabulary (e.g. 'fatal', 'last chance', 'real threat') is accompanied by the striking visuals of catastrophes which we experience or will experience due to climate change. In some cases, the layout of the blog entry is inspired by Hollywood blockbusters with fantastic images of sinking landmarks and scenes of destruction.

The 'alarmist' approach to climate change is not unique to the online discussion, in fact, the dramatization of this environmental problem has been one of the questionable sides of the traditional media coverage. Whilst the nature and scale of climate change, of course, involves a certain degree of 'drama', the extreme of apocalyptic discourse has been associated with 'uneven and sporadic reporting' which leads to a 'counterproductive' public response (Hulme 2007: 127). Thus making people more fatalist in their perceptions of climate change which takes away from their desire to be 'motivated to devise sustainability strategies' as 'life [is seen] as a lottery, with outcomes decided by chance' (Seyfang 2004: 328).

\section{Political games of climate change: 'who shall win?'}

The framing of climate change as a political problem prevailed during the UN conference in Lima, where bloggers relying on traditional media articles explained the predicaments of the subject matter (e.g. Fedorov 2014). The category included almost one third of all entries $(n=100,27 \%)$ but as in other cases, the political nature of the discussion did not result in a homogeneous perception of climate change - it was presented by some bloggers 'as an important international problem' $(\mathrm{n}=55,55 \%)$ and by others as 'a political game' $(\mathrm{n}=15$, $15 \%$ ). The latter is reminiscent of conspiratorial thinking, and re-introduced the Cold War rhetoric where even environmental problems are either caused by 'enemies' from the West or 
that the whole concept of climate change was created only to make Russia lose economically and politically.

CDA suggests the meaning of text is not restricted by what is written in the particular blog entry, but light is shed through additional discursive elements. For example, one blogger whilst acknowledging the existence of anthropogenic climate change bluntly states that 'all evil comes from America' (swet400 2014). In her/his profile description it is stated that 'I don't like fascism including the American one. I want Russia to be free', making it ambiguous whether s/he genuinely believes in the US' detrimental contribution to the world's climate or whether s/he is using the climate change topic to reproduce practiced narratives of RussianUS antagonism. In some blog entries the existence and seriousness of anthropogenic climate change is ignored and attention is only paid to Russia, that suffers from the 'oil plot' created by the Western world. The idea of climate change political games is then taken to the extreme by the supporters of the conspiracy theories where the 'climate change myth' is described as a shield to gain certain political goals (e.g. dmitri_obi 2014).

One of the most surprising findings within this category has become the absence of open criticism of Russian climate change policy with only one (out of 100) blog entry openly challenging the government's 'resource oriented' economy. An entry written by a Moscow environmental organisation, 'Eco defence', is dedicated to environmentalists' protests and its vision of problems in the Russian economy (ecmoru 2014):

Russia's economy is moving in a vicious circle, when money, earned by the exploitation of natural resources, is partly stolen, and partly re-invested into the development of new resources. [...] their development brings less revenue, but it brings more and more damage to ordinary citizens, the environment and Earth's climate.

It should be noted that overall the text is written not in a confrontational way, but as an appeal to the state to find a solution, which will benefit the economy, people and climate. The entry did not provoke any comments from readers.

Politics is considered to be one of the key factors shaping the climate change coverage in the traditional media and public discourse on that matter (Poberezhskaya 2016). As the analysis demonstrates, the Russian blogosphere follows similar patterns - whilst politics do play a prominent role in climate change discussions, bloggers seem to fail to initiate any critical assessment of what Russia as a state has done to contribute to climate change and what it can do differently. Furthermore, the entries do not exhibit any sense of a collective or personal responsibility (with a few exceptions) for this environmental degradation and as in the case of conspiratorial discussion the problem acquires an intangible nature, where guilt is allocated to an abstract global community which needs to deal with it urgently or it is disregarded altogether as just a product of political games.

\section{Online (anti-)environmentalism: 'marching together?'}

In the Russian blogosphere, environmental activism is one of the least popular categories with only 47 entries discussing it (13\%). The blogs were used to advertise future protests or to appeal to readers to support the 'good cause' and take part 'in the biggest climate mobilisation in history’ (People's Climate March) (Shakhova 2014). However, even articles that were ostensibly about something as pertinent to climate change as the climate march, were often 
found to be using climate change to address an unrelated or tenuously related agenda. Some bloggers reported on the climate marches with little indication of their own personal conviction that the issue of climate change was important. Antizoomby (2014), for example, re-publishes photographs of the protest in New York and thus draws attention to the climate change activism taking place there. However, his/her brief comments instead offer a compelling narration of how peaceful environmental action resulted in cruel police arrests. The entry, therefore, invites us to make up our own minds about policing in the USA, whilst leaving the significance of the issue protested against ambiguous. This shows that not all mentions of climate change related topics are focussed directly on consciously addressing climate change as an issue, but it also demonstrates that climate change discourse is partly constituted by very loosely related issues like the appropriate way to express and police political discontent.

Environmental movements have also become the object of climate sceptic criticism in text that often, in highly emotive and even extreme vocabulary, attempts to disregard either the 'aim' of environmental action (mitigating anthropogenic climate change) or the 'means' the activists advocate (environmental campaign strategies or policy action). In fact, almost one third of the entries in this category $(n=14,29 \%)$ discussed environmentalism from a negative perspective. For example, Zlatasoul (2014), opening with a very strong headline ('B****rds calling to join the march under 'deceitful' slogans. Be careful!'), warns people to stay away from any climate marches, because:

They will gather a crowd for some innocent cause, will make it drink some magic tea like in Kiev and here goes a battle for Euro-integration. Russians, attention!!!! Crowds of thousands of people only benefit the enemies of our state!!!!

The publicity stunt organised by Greenpeace during the climate conference in Lima (which involved displays next to the unique Nazca images) provoked another negative outcry among the selected online texts with such titles as 'Greenpeace is a gathering of retards' (Matveychev 2014), 'That's right, they are called the environmental Taliban' (irlandets01 2014) or 'The idiots from Greenpeace' (viatcheslav 2014). The negative perception of the environmental movements and activists subsequently discredits the actual problem of climate change, which becomes just a 'plot' of 'eco-fascism'.

A small number of texts actively promoting environmental messages can be divided into two groups: personal blogs of people who share these ideas (e.g. ecostrat, ecology_ru, arctic_blog), and blogs supported by environmental organisations (e.g. Oxfam-Russia, 'Eco defense'). Overall, there were 20 (43\%) blog entries of this kind and it can be concluded (based on the descriptions written in the profiles of the blogs' authors) that these people and organisations are actively pursuing voiced ideas not only in the online environment but also in the real world.

Interestingly, the environmental orientation of the blog does not assume its unconditional support of the idea that anthropogenic climate change exists and it is bad for people. For example, the blog produced by the 'educational' project Ecoleaks, whose authors identify themselves as 'environmental sceptics' (Ecoleaks 2015), propagates the ideas of diminishing anthropogenic influence on the environment but through the 'real measures', not some 'idle talk and speculations' (the latter includes the anthropogenic character of climate 
change, over-population of the planet and so on). The fact that these people position themselves as environmentalists, gives them greater authority in diminishing the 'idea' of anthropogenic climate change. Arguably, the internet contributes to the new understanding of the 'expert' where the authority of the sources is not proven by existing professional credentials, but by the popularity of the author and the affirmative nature of the blogs' rhetoric.

\section{Discussion}

The analysis showed a palette of climate change discourses, with some blog entries contributing to the 'incivility' (Collins and Nerlich 2015) of the online climate discussion and others either raising the alarm about the deadly nature of climate change or championing a conspiratorial understanding of the problem. This observation to some degree correlates with a finding made by Wood and Douglas (2013) who argue that a hostile tone of communication is more likely to be found among online comments which support more conventional explanations of the event or phenomenon (rather than among 'conspiracists'). Therefore, whilst the use of obscene language on its own does not add to the creation of a particular vision of climate change with both sceptics and 'acceptors' occasionally using it, arguably, the alarmist messages and conspiracies contribute to the readers' attitude of hopelessness towards the problem. Conspiratorial thinking is more likely to thrive in a situation where people are in 'powerless social positions' (Douglas \& Sutton 2011) which could be explained by Russia's political and economic situations where people often find themselves either being too preoccupied with financial problems or not risking confrontation with the somewhat authoritarian government. At the same time, the exposure to climate change conspiracies diminishes people's desire to cut their carbon footprint, making them content with their established way of life since the blame is allocated somewhere else (Douglas and Sutton 2015), or more apolitical overall as the solution is not in their hands (Jolley and Douglas 2014).

A relatively limited number of entries act as a platform for environmental activism and even within this sample, a large proportion aims to discredit the environmental movement: this fact does not fit with the proposition that the internet is extensively used by activists to communicate their agenda (Jun 2011). These findings make sense within the Russian context where, for decades, environmental movements have been experiencing a number of barriers including a lack of funding, restrictive state policies and the public's suspicious attitude, especially towards international organisations (e.g. Greenpeace or WWF) (Henry 2010). The limited or sceptical nature of online climate activism also fits with another international trend: where the internet is used to express doubts about the legitimacy of the climate change problem or its mitigation or adaptation policies (e.g. Gavin and Marshall 2011, Lockwood 2010).

The conducted analysis also reinforces the argument that people who express certain opinions online, already actively propagate these ideas in the off-line world (Athique 2013). Thus, the blogs behave as 'echo-chambers' which have limited effect on people who are indifferent to the topic, and often fail to change people's minds, but instead re-inforce existing beliefs and values (Garrett 2009). It is not unique to the Russian context and has been supported by a number of studies which reveal that 'most individuals engaged in online 
discussions are embedded within communities of like-minded users' (Williams et al. 2015: 136; see also Itkonen 2015).

Despite the limited capacity of the internet to engage broader groups of people, Hestres (2014: 237) argues that it still plays an important role in 'a full-blown social movement to tackle climate change' and turn people into 'long-term activists'. Of course, this is also relevant for people who are prone to doubt climate change's existence; a number of online investigations that 'uncover the truth' is likely to cement their sceptical views. Indeed, it seems that the Russian blogosphere still contains a great number of climate sceptical discussions that call into question the existence, origins and/or consequences of climate change (with 52 blog entries completely denying climate change's existence and another 39 openly refuting its anthropogenic nature). This makes it different to the content of the traditional media outlets, which have mostly moved beyond these basic questions (Poberezhskaya 2016). ${ }^{7}$ As Taddicken (2013: 46) observes, for the climate sceptics and deniers, the "internet may serve as an "escape" from these pro-anthropogenic and normative positions', therefore turning the internet's praised freedom against climate science.

As stated in the introduction, along with the identification and analysis of the existing themes in the researched data, the article also aimed to examine if blogs can act as an alternative to the traditional media in Russia. The analysis demonstrated that the studied blog entries tend to repeat, arguably, one of the most important trends in traditional media concerning their coverage of climate change. With only one entry openly challenging Russian state policy on climate change, and with a small number of entries dedicated to the critique of people's environmentally damaging lifestyle, there is an evident absence of sound assessment of Russia's questionable climate policy. Furthermore, the corpus lacks originality with 144 $(39 \%)$ entries being either reposts of other blog entries $(n=61)$ or 'copy-pastes' of articles from the traditional media $(n=83)$. This finding has come about as a surprise, as over the last few years, Russian bloggers have proved to be quite instrumental in expressing and encouraging oppositional views in the country (Etling et al. 2010). It seems to be that climate change has not reached that critical point yet at which the online community questions not only the role of the mysterious 'Planet $X$ ' but also their own state leaders.

New media in the Russian case of climate change communication represents a fascinating object of study and as this research study has quite a narrow focus (looking at coverage of three events in one blogging platform), it only touches the surface of the range of issues that can be investigated. In sum, the findings show that the studied online discourse is dominated by the discussion of climate change's negative consequences and the political aspects of the problem. This can be seen as a positive trend, which provides more channels for the public to learn about the problem. However, the online discussion also contains more references to sceptical or conspiratorial messages taking the development of climate change discourse back in time. Ytterstad (2008) highlights the important role of politicians who use the platform to offer solutions to climate change problems, and more importantly how blogs allow these ideas to be democratically-debated. Unfortunately, in the studied case, the blogs failed to act as an alternative platform for an active pro-environmental discussion and did not

\footnotetext{
${ }^{7}$ The argument would benefit from a substantial comparison between online and offline media scepticism.
} 
demonstrate their capacity to develop a critical analysis of state involvement in climate degradation. Therefore, even though it could be stated that climate change online discourse does exist in Russia, the trajectory of its development is uncertain. This will require further investigation of how various online platforms have been utilised, how the public and the state react to climate change related messages and whether online discussion of climate change in Russia facilitates more democratic environmental politics.

\section{Bibliography}

Alexanyan, K. (2009) Social networking on RuNet: the view from a moving train, Digital Icons: Studies in Russian, Eurasian and Central European New Media, 1 (2): 1-12.

Andonova, L. (2008) The climate regime and domestic politics: the case of Russia, Cambridge Review of International Affairs, 21: 483-504.

Antizoomby (2014) Massovye protesty i aresty ekologov v N'yu-Yorke', LiveJournal, http://antizoomby.livejournal.com/319656.html, (accessed 20 March 2015).

Athique, A. (2013) Digital Media and Society: an Introduction. Cambridge: Polity.

Bedritsky, A. (2014) 'Zayavlenie spetspredstavitelya Prezidenta po voprosam klimata Aleksandra Bedritskogo', http://state.kremlin.ru/news/47115/print, (accessed 23 January 2015].

Bosch, T. (2012) 'Blogging and tweeting climate change South Africa', Ecquid Novi: African Journalism Studies, 33(1): 44-53.

Buchner, B. and Dall'Olio, S. (2005) Russia and the Kyoto Protocol: the long road to ratification, Transition Studies Review, 12: 349-382.

Carvalho, A. (2007) Ideological cultures and media discourses on scientific knowledge: re-reading news on climate change, Public Understanding of Science, 16: 223-243.

Carvalho, A. (2008) Media(ted) discourse and society, Journalism Studies, 9(2): 161-177.

Chay, S. and Sasaki, N. (2011) Using online tools to assess public responses to climate change mitigation policies in Japan, Future Internet, 3 (2): 117-129.

Collins, L. and Nerlich, B. (2015) Examining user comments for deliberative democracy: a corpus-driven analysis of the climate change debate online, Environmental Communication, 9:2, 189-207.

dirty_as_dj (2014) 'Pro Piter i dr.', LiveJournal, http://dirty-asdj.livejournal.com/85111.html, (accessed 20 March 2015).

dmitri_obi (2014) 'Poslezavtra mir zamret. Pochemu uchenye govoryat o novom lednikovom periode v 2014-15 godu. 28.11.2014, LiveJournal, http://dmitriobi.livejournal.com/profile, (accessed 20 March 2015).

Douglas, K. and Sutton, R. (2015) 'Climate change: Why the conspiracy theories are dangerous', Bulletin of the Atomic Scientists, 71(2): 98-106. 
Douglas, K. M. and Sutton, R. M. (2011), Does it take one to know one? Endorsement of conspiracy theories is influenced by personal willingness to conspire. British Journal of Social Psychology, 50: 544-552.

Drobyshev, V. (2014) 'Shest' faktov o belykh medvedyakh', LiveJournal, http://vitalidrobishev.livejournal.com/5113633.html, (accessed 20 March 2015).

ecmoru (2014) 'Ekoaktivisty proveli piket v tsentre Moskvy k sammitu OON po klimatu', LiveJournal, http://ecmoru.livejournal.com/1166815.html, (accessed 20 March 2015).

Ecoleaks (2015) 'O proekte Ecoleaks', http://ecoleaks.info/about/, (accessed 20 March 2015).

Elgesem, D., Steskal, L. and Diakopoulos, N. (2015) 'Structure and Content of the Discourse on Climate Change in the Blogosphere: The Big Picture', Environmental Communication, 9:2, 169-188

Eroshin, A. (2014) 'Letniy sneg - kolebanie zemli stalo bolee ochevidnym', LiveJournal, http://andrey-eroshin.livejournal.com/22655.html, (accessed 20 March 2015).

Etling, B., Alexanyan, K., Kelly, J., Faris, R., Palfrey, J. and Gasser, U. (2010) 'Public discourse in the Russian blogosphere: mapping RuNet politics and mobilization'. Berkman Center Research Publication, No. 2010-11, October 19: 1-46.

Fedorov, D. (2014) 'Delegatsiya minprirody Rossii prinimaet uchastie v 20-y konferentsii storon ramochnoy konventsii OON', LiveJournal, $\underline{\text { http://dm- }}$ fedorov.livejournal.com/967202.html, (accessed 20 March 2015).

Flew, T. (2011) New Media, 3rd Edition, Oxford: Oxford University Press.

FOM (2014) 'Internet v Rossii: dinamika proniknoveniya. Osen' 2014', http://fom.ru/SMI-i-internet/11889, (accessed 24 March 2015).

FOM (2016a) 'Internet v Rossii: dinamika proniknoveniya. Zima 2015-2016', http://fom.ru/SMI-i-internet/12610, (accessed 25 August 2016).

Fossato, F., Lloyd, J. and Verkhovsky, A. (2008). The Web That Failed: How Opposition Politics and Independent Initiatives Are Failing on the Internet in Russia. Oxford: Reuters Institute for the Study of Journalism.

Freelon, D. (2013) Discourse architecture, ideology, and democratic norms in online political discussion, New Media \&Society: 1-20, doi: 10.1177/1461444813513259 (accessed 10 March 2014).

Garrett, R. K. (2009) Echo chambers online?: Politically motivated selective exposure among Internet news users, Journal of Computer-Mediated Communication, 14 (2): 265285.

Gavin, N. and Marshall, T. (2011) 'Mediated climate change in Britain: scepticism on the web and on television around Copenhagen', Global Environmental Change, 21/1: 10351044.

Henry, L. (2010) Between transnationalism and state power: the development of Russia's post-Soviet environmental movement, Environmental Politics, 19: 756-781. 
Hestres, L. (2014) Preaching to the choir: internet-mediated advocacy, issue public mobilization, and climate change, New Media \&Society, 16 (2): 323-339.

Hulme, M. (2009) 'Mediated Messages about Climate Change: Reporting the IPCC Fourth Assessment in the UK Print Media'. In: T. Boyce and J. Lewis (eds.) Climate Change and the Media, New York: Peter Lang Publishing: 117-128.

irlandets01 (2014) 'Vot pravil'no ikh nazyvayut ekologicheskim Talibanom', LiveJournal, http://irlandets01.livejournal.com/1600027.html, (accessed 20 March 2015).

Itkonen, J. (2015) 'Social ties and concern for global warming', Climatic Change, doi: 10.1007/s10584-015-1424-0.

Izvestiya (1997) 'Rossiya Mozhet Zarabotat' na Poteplenii Klimata', Izvestiya, 16 December 1997.

Jolley, D. and Douglas, K. (2014) The social consequences of conspiracism: Exposure to conspiracy theories decreases intentions to engage in politics and to reduce one's carbon footprint, British Journal of Psychology, 105(1): 35-56.

Jun, J. (2011) How climate change organizations utilize websites for public relations, Public Relations Review, 37 (3): 245-249.

Katz-Kimchi, M. and Manosevitch, I. (2015) 'Mobilizing Facebook Users against Facebook's Energy Policy: The Case of Greenpeace Unfriend Coal Campaign', Environmental Communication, 9:2, 248-267.

Koltsova, O. and Shcherbak, A. (2014) 'LiveJournal Libra!': The political blogosphere and voting preferences in Russia in 2011-2012, New Media and Society, doi: $10.1177 / 1461444814531875,1-18$.

Koltsova, O., Koltcov, S., \& Nikolenko, S. (2016) Communities of co-commenting in the Russian LiveJournal and their topical coherence, Internet Research, 26(3): 710-732.

Korppoo, A. (2008) Russia and the post-2012 climate regime: foreign rather than environmental policy, UPI Briefing Paper, 23.

Koteyko, N., Jaspal, R. and Nerlich, B. (2013) Climate change and "Climategate" in online reader comments: a mixed methods study, The Geographical Journal, 179 (1): 7486.

Kungurov, A. (2014) 'Zombo-liberasty pozeleneyut', LiveJournal, http://kungurov.livejournal.com/102114.html, (accessed 20 March 2015).

Ladle, R., Jepson, P and Whittaker, R. (2005) Scientists and the media: the struggle for legitimacy in climate change and conservation science, Interdisciplinary Science Reviews, 30(3): 231- 240.

Lewandowsky, S. (2014) Conspiratory fascination versus public interest: The case of 'climategate'. Environmental Research Letter, 9, Article 11104.

Lievrouw, L. (2011) Alternative and activist new media. Cambridge: Polity.

Lockwood, A. (2008) 'Seeding doubt: how sceptics use new media to delay action on climate change'. Association for Journalism Education (AJE) Annual Conference 'New Media, New Democracy?', Sheffield University, 12 ${ }^{\text {th }}$ September 2008. 
Lockwood, A. (2010) 'Seeding doubt: How sceptics have used new media to delay action on climate change', Geopolitics, History and International Relations, 2(2): 136-164.

Martin, N. and Rice, J. (2014) Rebalancing climate change debate and policy: an analysis of online discussions, Environmental Policy and Governance, 24: 338-350.

Matthews, P. (2015) 'Why Are People Skeptical about Climate Change? Some Insights from Blog Comments', Environmental Communication, 9(2): 153-168

matveychev_oleg (2014) 'Greenpeace - sborishche nedoumkov', LiveJournal, http://matveychev-oleg.livejournal.com/1759589.html, (accessed 20 March 2015).

Newell, R. and Dale, A. (2015) 'Meeting the Climate Change Challenge (MC3): The Role of the Internet in Climate Change Research Dissemination and Knowledge Mobilization', Environmental Communication, 9:2, 208-227,

O'Neill, S. and Boykoff, M. (2011) The Role of New Media in Engaging Individuals with Climate Change, In: Whitmarsh L, O'Neill SJ, and Lorenzoni I (eds.) Engaging the Public with Climate Change: Communication and Behaviour Change. London: Earthscan: 233251.

Oates, S. (2013) Revolution Stalled: the Political Limits of the Internet in the Post-Soviet Sphere, Oxford: Oxford University Press.

Olausson, U. (2009) Global warming - global responsibility? Media frames of collective action and scientific certainty, Public Understanding of Science, 18 (4): 421-436.

Oldfield, J. (2001) Russia, systemic transformation and the concept of sustainable development, Environmental Politics, 10: 94 - 110.

Panchenko, E. (2011) Integratsiia internet-SMI i sotsial'nykh setei v Runete: novaya publichnaia sfera ili prostranstvo kontrolia?, Digital Icons: Studies in Russian, Eurasian and Central European New Media, 5: 87-118.

People's Climate March (2015), http://peoplesclimate.org/, (accessed 24 March 2015).

Poberezhskaya, M. (2016) Communicating Climate Change in Russia: state and propaganda. Routledge: Abington.

President of the Russian Federation (30 September 2013) Decree no. 752 'On Reduction of Greenhouse Gas Emissions'.

Rantanen, T. (2001) The old and the new: communication technology and globalization in Russia, New Media and Society, 3(1): 85-105.

Renz, B. and Sullivan, J. (2013) Electronic resources and the study of political elites in Russia, Europe-Asia Studies, 65 (10): 1898-1911.

Reporters Without Borders (2016) 'Draconian new law tightens control over communication in Russia', https://rsf.org/en/news/draconian-new-law-tightens-controlover-communication-russia, (accessed 13 September 2016).

Rettberg, J. (2008) Blogging. Cambridge: Polity.

Roshydromet (2014) The Second Assessment Report of Climate Change and its Consequences in the Russian Federation. Moscow: Roshydromet. 
Schafer, M. (2012) Online communication on climate change and climate politics: a literature review, WIREs Climate Change, 3: 527-543.

Schafer, M. and Schlichting, I. (2014) Media representations of climate change: a metaanalysis of the research field, Environmental Communication, 8(2): 142-160.

Seyfang, G. (2004) Consuming values and contested cultures: a critical analysis of the UK strategy for sustainable consumption and production, Review of Social Economy, 62(3): 323-338

Shakhova, E. (2014) 'Klimaticheskiy marsh', LiveJournal, http://matilda-ija.livejournal.com/642383.html, (accessed 20 March 2015).

Spence A, Poortinga W, Butler C and Pidgeon NF (2011) Perceptions of climate change and willingness to save energy related to flood experience. Nature Climate Change, 1: 46-49.

swet400 (2014) 'Vse zlo ot Ameriki', LiveJournal, http://swet400.livejournal.com/244690.html, (accessed 20 March 2015).

Taddicken, M. (2013) Climate change from the user's perspective. The impact of mass media and internet use and individual and moderating variable on knowledge and attitudes, Journal of Media Psychology, 25(1): 39-52.

Takahashi, B., Edwards, G., Roberts, J. T. and Duan, R. (2015) 'Exploring the Use of Online Platforms for Climate Change Policy and Public Engagement by NGOs in Latin America', Environmental Communication, 9:2, 228-247

Tynkkynen, N. (2010) A Great Ecological Power in global climate policy? Framing climate change as a policy problem in Russian public discussion, Environmental Politics, 19: 179-195.

Uldam, J. and Askanius, T. (2013) Online civic cultures: debating climate change activism on YouTube, International Journal of Communication, 7: 1185-1204.

UNFCCC (2015) National greenhouse gas inventory data for the period 1990-2013, http://unfccc.int/resource/docs/2015/sbi/eng/21.pdf, (accessed 1 September 2016)

UNFCCC (n.d.) Status of Ratification of the Kyoto Protocol, http://unfccc.int/kyoto_protocol/status_of_ratification/items/2613.php, (accessed 1 September 2016).

van Dijk, T. (2001) 'Critical Discourse Analysis, In: D. Tannen, D. Schiffrin and H. Hamilton (eds.) Handbook of Discourse Analysis, Oxford: Blackwell: 352-371.

viatcheslav (2014) 'Idioty iz Greenpeace', LiveJournal, http://viatcheslav.livejournal.com/401321.html, (accessed 20 March 2015).

Vinogradov, D. (2006) Russian internet remains an island of free speech and civil society, Russian Analytical Digest, 9: 12-15.

Williams, H., McMurray, J., Kurz, T. and Lambert, F. (2015) 'Network analysis reveals open forums and echo chambers in social media discussions of climate change', Global Environmental Change, 32: 126-138. 
Wilson Rowe, E. (2009) Who is to blame? Agency, causality, responsibility and the role of experts in Russian framings of global climate change, Europe-Asia Studies, 61/4: 593619.

Wood M. and Douglas K. (2013) “"What about building 7?” A social psychological study of online discussion of 9/11 conspiracy theories', Frontiers in Psychology, 4: 409. doi:10.3389/fpsyg.2013.00409.

World Bank (2010) Public Attitudes toward Climate Change: Findings from a MultiCountry Poll, The World Development Report, July 2010.

World Bank (2012) Total Greenhouse Gas Emissions (kt of CO2 equivalent), http://data.worldbank.org/indicator/EN.ATM.GHGT.KT.CE?year_high_desc=true (accessed 1 September 2016).

Ytterstad, A. 2008. "It is we-you and me, who possess real power": Blogging Protests against Official Norwegian Policy on Climate Change. Intercultural Communication Studies, 17(3), pp.77- 92.

Zlatasoul (2014) 'Vyrodki prizyvayut vyiti na marsh, pod "lzhivymi" lozungami. Bud'te bditel'ny!', LiveJournal, http://zlatasoul.livejournal.com/48364.html, (accessed 20 March 2015). 